\title{
POŠTA
}

TELEKOMUNIKÁCIE A

ELEKTRONICKY OBCHOD

\section{VYUŽÍVANIE ELEKTRONICKÝCH SLUŽIEB INTEGROVANÉHO SERVISNÉHO MIESTA OBČANMI}

\author{
Dominik Laitkep ${ }^{1}$, Simona Jaculjaková ${ }^{2}$, Katarína Repková Štofková ${ }^{3}$
}

\begin{abstract}
The Slovak postal market is part of the global postal market. Slovak Post also wants to provide postal services, which take into account new market trends that reflect the changing needs of postal users. One of modern services is the Integrated service point for citizens (IOMO), which makes it easier for them to handle official matters, the e-Government service. The aim of the expert article is to point out the declining use of IOMO services in Slovakia.
\end{abstract}

Keywords: digitalization, Slovak Post, e-Government

\section{Úvod}

Hlavné zmeny v štruktúre spoločnosti nastali v druhej polovici 20. storočia. Zmeny nastali na základe nástupu moderných informačných technológií (IKT). V tomto období prebiehala transformácia celej spoločnosti, a začali vznikat' prvé teoretické východiská spojené s transformáciou spoločnosti a ekonomiky a to najmä na ekonomiku digitálnu. [1]

Digitálnu ekonomiku je možné charakterizovat' ako novodobú ekonomiku, ktorá využíva informačno-komunikačné technológie $\mathrm{v}$ celom spektre produktov a služieb. Tie prenikajú do tradičnejších, kl'účových odvetví národného hospodárstva, ktorými sú pol'nohospodárstvo, zdravotníctvo, bankovníctvo, vzdelávanie, doprava, kultúra, výskum a vývoj, priemysel, verejná správa, pošty a telekomunikácie a pod. Pošta a telekomunikácie sú súčast'ou odvetvia národného hospodárstva.

\section{Teoretické východiská riešenej problematiky}

Digitálna ekonomika umožňuje využívat' nové biznis modely, na základe ktorých sú vytvorené inovatívne riešenia oproti tradičným, ktoré nebolo možné doposial' zrealizovat'. Podl'a autorov Gerogiadisa, Stiakakisa a Ravindrana digitálna ekonomika ponúka rôzne možnosti na dosiahnutie tradičných hospodárskych a sociálnych aktivít s využitím IKT. [2]

Digitálnu ekonomiku možno v širších súvislostiach chápat' ako prepojenie digitálnej ekonomiky s obchodnými činnost’ami. Je nutné podotknút', že na základe tohto tvrdenia nie je súčast’ou digitálnej ekonomiky iba realizovanie rôznych obchodných transakcií, ale aj inovácií v oblasti podnikania, ktoré prispievajú k rozvoju digitálnej ekonomiky. [3]

Poštové služby je možné definovat' ako jeden z nástrojov, ktorý je pre uskutočnenie obchodu a komunikácie nevyhnutný. Poštové služby sa poskytujú za účelom vládnych, sociálnych a komerčných aktivít s nevyhnutnou infraštruktúrou podporou, s ktorou sú

\footnotetext{
${ }^{1}$ Ing. Dominik Laitkep, Fakulta prevádzky a ekonomiky dopravy a spojov, Katedra spojov, Žilinská univerzita v Žiline, e-mail: dominik.laitkep@fpedas.uniza.sk

${ }^{2}$ Ing. Simona Jaculjaková, Fakulta prevádzky a ekonomiky dopravy a spojov, Katedra spojov, Žilinská univerzita v Žiline, e-mail: simona.jaculjakova@fpedas.uniza.sk

${ }^{3}$ doc. Ing. Katarína Repkova Štofková, PhD., Fakulta prevádzky a ekonomiky dopravy a spojov, Katedra spojov, Žilinská univerzita v Žiline, e-mail: katarina.stofkova@fpedas.uniza.sk
} 
prepojené rôzne oblasti poskytujúce finančné služby, služby e-Commerce, služby eGovernmentu a pod. [4]

Medzi základné charakteristiky eGovernmentu patrí využívanie informačnokomunikačných technológií verejnými inštitúciami pre zaistenie výmeny informácií s občanmi, podnikmi a inými verejnými inštitúciami za účelom zvyšovania efektívnosti, zlepšenia vnútorného fungovania a poskytovania rýchlych, dostupných, na užívatel'a zameraných, kvalitných elektronických služieb. [5]

Trh poštových a telekomunikačných služieb sa v moderných časoch rýchlo vyvíja. Tento rozvoj je vyvolaný najmä inováciami v oblasti automatizácie, robotizácie či digitalizácie a fenoménom Industry 4.0. Priemysel 4.0 je označenie pre súčasný trend digitalizácie, s ním súvisiaca automatizácia výroby a zmeny na trhu práce, ktoré so sebou prinášajú. $Z$ toho vyplýva, že všetky trhy aj ten poštový, má tendenciu rozmachu v oblasti inovácií a poskytovaní nových služieb na poštovom trhu.[6]

Kvôli pôsobeniu jednotlivých odvetví a konkurenčných trhov na trh poštový dochádza k rýchlym zmenám u poštových služieb. Je teda zrejmé, že pri jednotlivých poštových službách sa mení tradičný imidž, čoho následkom je poskytovanie služieb prostredníctvom moderných poskytovatel'ov, ktorí sú komplexne hospodárskymi poskytovatel'mi, nielen hodnotnejších, ale aj inovatívnejších služieb, tých elektronických. [7]

Elektronické služby je možné charakterizovat' ako elektronickú činnost', ktorá uspokojuje určité potreby občanov. Podstatou elektronických služieb tkvie vo vzdialenom prístupe a vo využití vzdialeného elektronického spojenia pre získanie príslušnej služby. Podl'a autorov Kardarasa a Karaostasa sú elektronické služby vnímané ako tradičné služby s tým rozdielom, že sú poskytované prostredníctvom siete Internet a je možné konštatovat', že elektronické služby sú integrované s jednotlivými procesmi a technológiami, prostredníctvom ktorých je možné vyriešit' jednotlivé požiadavky zákazníkov. [8]

Svetová poštová únia rozdel'uje služby elektronické služby poskytované poštovými operátormi na kategórie:

- služby e-Post a Služby štátu,

- služby e-Commerce,

- e-Finančné a e-Platobné služby,

- podporné služby.[9]

Slovenský poštový trh je samozrejme súčast'ou celosvetového globálneho poštového trhu kde je nástup elektronizácie prioritou. Realizovanie elektronizácie a digitalizácie poštových služieb je uskutočnené na základe prudko rozvíjajúcich sa IKT a na základe osobitného rozvoja elektronizácie štátnej správy a služieb e-Governmentu.

Pomocou elektronizácie napríklad dochádza k výraznému znižovaniu spracovania objemu listových zásielok, čo ovplyvňuje aj poskytovanie univerzálnej služby. Pod univerzálnou službou sa rozumie ponuka určitých poštových služieb, ktorá zabezpečuje minimálne uspokojenie určitých potrieb všetkých užívatel'ov poštových služieb na území SR. Rozvoj IKT taktiež podporuje zavádzanie nových elektronických poštových služieb a dochádza aj k inovácii ich existujúcich poštových služieb tak, aby zodpovedali meniacim sa potrebám zákazníkov. [10]

Slovenská pošta - SP, a. s. je národným poštovým operátorom v SR od 1.1.1993. národný poštový operátor poskytuje portfólio jednotlivých služieb, širokej verejnosti prostredníctvom koncentrovanej poštovej siete. [11] V rámci realizácie inovácí́ v SP, a. s. sa poštový operátor pripravuje na prichádzajúcu digitalizáciu spoločnosti, a preto sa zameriava na poskytovanie aj rôznych inovatívnych služieb. Medzi inovatívne poštové služby je možné zaradit' aj poskytovanie elektronických služieb štátu, ktoré sú nazvané Integrované obslužné miesto občana (IOMO). SP, a. s. je poskytovatel'om asistovaných služieb, o ktoré môže požiadat' fyzická ale aj právnická osoba. Medzi elektronické služby IOMO možno zaradit' výpis 
$\mathrm{s}$ registra trestov, odpis z registra trestov, výpis z listu vlastníctva, výpis z obchodného registra, osvedčenie dokumentov zaručenou konverziou atd'. SP, a. s. poskytuje dané služby asistovane. [12]

\section{Ciel' a metodika}

Ciel'om odborného článku je poukázat' na využívanie služieb IOMO na Slovensku z pohl'adu oddelenia dátovej kancelárie ktorá je súčast'ou Ministerstva investícií, regionálneho rozvoja a informatizácie. Dáta $\mathrm{s}$ ktorými sme pracovali a vyňali $\mathrm{z}$ modulov národného informačného systému pochádzajú zo systému IOMO, ktoré prevádzkuje SP, a. s., Klientske centrum a Združenie miest a obcí Slovenska. [11]

Vzhl'adom na ciel' odborného článku bolo potrebné potrebné analyzovat' poštový trh z pohl'adu rozvoja digitalizácie a ozrejmit' teoretické východiská riešenej problematiky.

V rámci realizácie daného výskumné článku boli taktiež použité nasledovné metódy, ktorými sú:

- Metóda excerpovania - táto metóda bola využitá pri štúdiu a využití internetových a knižných zdrojov, potrebných pre spracovanie teoretickej časti vedeckého článku.

- Metóda analýzy - prostredníctvom tejto metódy bolo analyzované, využívanie elektronických služieb e-Governmentu, ktoré sú poskytované prostredníctvom IOMO, ZMOS a Klientskych centier.

- Metódy indukcie a dedukcie - na základe týchto metód boli podrobne analyzované výsledky sekundárneho výskumu, týkajúce sa využívania služieb e-Governmentu na jednotlivých prístupových miestach, ktoré realizovalo Oddelenie dátovej kancelárie.

- Metódy syntézy - na základe tejto metódy boli stanovené jednotlivé závery, v rámci skúmanej problematiky.

\section{Výsledky}

Oddelenie dátovej kancelárie spadá pod Sekciu informačných technológií verejnej správy a je zároveň súčast’ou Ministerstva investícií, regionálneho rozvoja a informatizácie, uskutočnilo kvantitatívnu analýzu dát za účelom zistenia skutočného využívanie služieb IOMO za obdobie od 1.1.2016 do 1.11.2020.

Celkový počet využívaných služieb od 1.1.2016 do 1.11.2020, ktorý bol poskytovaný občanom a podnikatel'ským subjektom prostredníctvom SP, a. s., ZMOS a Klientskeho centra môžeme vidiet' v nasledujúcej tabul'ke 1 .

Tabul'ka 1. Poskytovanie služieb e-Governmentu

\begin{tabular}{|c|c|}
\hline Poskytovatelia služieb IOMO & Celkový počet výstupov \\
\hline ZMOS & 12137 \\
\hline SP, a. S. & 2609327 \\
\hline Klientske centrá & 0 \\
\hline Spolu & 2621464 \\
\hline
\end{tabular}

Zdroj: DataLab, Informačný panel IS IOM. [online]. [cit. 2021-09-10]. Dostupné na internete: $<$ https://datalab.digital/informacny-panel-is-iom/>.

Z tabul'ky je možné poukázat' na to, že najviac poskytovaných služieb bolo realizovaných na SP, a. S., a to v počte 2609327 výstupov. Ďalším, v poradí druhým poskytovatel'om týchto elektronických služieb sú jednotlivé obce a mestá, ktoré poskytli od roku 2016 do roku 2020 iba 12137 výstupov. Tretí poskytovatel' služieb IOMO, klientské centrá centrá nezrealizovali ani jeden výstup za sledované obdobie. [11]

Analyzovali tendenciu využívania služieb IOMO u jednotlivých poskytovatel'ov daných služieb. Prvým z nich je ZMOS - Združenie miest a obcí Slovenska. 
V roku 2016 zaznamenali poskytovatelia služieb IOMO 35 výstupov z informačného modulu IOMO, ktoré poskytujú jednotlivé obce a mestá.

Z celkového počtu poskytovaných výstupov bolo uskutočnených:

- 14 výpisov z listu vlastníctva,

- 6 výpisov z obchodného registra,

- 14 výpisov $\mathrm{z}$ registra trestov

- 1 odpis z registra trestov.

Počet výstupov zo služby IOMO za rok 2016 môžeme pripisovat' nedostatočnej informovanosti občanov a podnikatel'ských subjektov o možnosti realizovat' potrebné výstupy u jednotlivých obcí a miest, ktoré poskytujú služby IOMO. [11]

V nasledujúcom roku, roku 2017 bolo realizovaných 1533 záznamov, čo predstavovalo zvýšenie o 1498 výstupov oproti roku 2016. Z celkového počtu poskytovaných výstupov bolo realizovaných:

- 524 výpisov z listu vlastníctva,

- 617 výpisov z obchodného registra,

- 363 výpisov $z$ registra trestov

- 26 odpisov z registra trestov. [11]

V nasledujúcom roku 2018 bolo poskytnutých 4861 výstupov služby IOMO, čo v porovnaní s rokom 2017 predstavovalo nárast až o 3428 poskytnutých výstupov. Z celkového počtu poskytovaných výstupov za rok 2018 bolo realizovaných:

- 1586 výpisov z listu vlastníctva,

- 482 výpisov $z$ obchodného registra,

- 2677 výpisov $\mathrm{z}$ registra trestov,

- 214 odpisov $z$ registra trestov

- 2 zaručené konverzie.

Bol zaznamenaný aj znížený počet vydaných výstupov a to u výstupov z obchodného registra. Tento pokles pripisujeme vládnemu uzneseniu, ktorý upravuje Zákon č. 177/2018 Z., v ktorom sa nariad'uje zrušenie povinnosti predkladat' v listinnej podobe výpisy z obchodného registra a výpisy z listu vlastníctva, jednotlivým orgánom štátnej správy. Dané vládne nariadenie platí od 1.9.2018. [11,12]

V roku 2019 nastal celkový pokles využívania služieb IOMO, poskytovaných prostredníctvom jednotlivých obcí a miest. Počet výstupov služby IOMO za rok 2019 bol iba 3279 výstupov, čo predstavuje zníženie o 149 výstupov v porovnaní s rokom 2018. Z celkového počtu poskytovaných výstupov bolo realizovaných:

- 450 výpisov z listu vlastníctva,

- 253 výpisov z obchodného registra,

- 2373 výpisov z registra trestov,

- 141 odpisov $\mathrm{z}$ registra trestov

- 62 zaručených konverzií.

Pokles vo využívaní prezentovaných výstupov v roku 2019 pripisujeme najmä znižovaniu administratívnej zát’aže, nakol'ko od 1.1.2019 fyzické a právnické osoby nemusia predkladat' jednotlivým orgánom štátnej správy d'alší výstup z verejných registrov, ktorým je výpis $\mathrm{z}$ registra trestov. [11,12]

V roku 2020 bol zaznamenaný celkový pokles využívania služieb IOMO. Celkový počet výstupov za rok 2020 bol na úrovni 2332 výstupov. Z celkového počtu poskytovaných výstupov bolo realizovaných:

- 230 výpisov z listu vlastníctva,

- 231 výpisov $z$ obchodného registra,

- 1768 výpisov $\mathrm{z}$ registra trestov, 
- 84 odpisov z registra trestov

- 19 zaručených konverzií.

Pokles dopytu po jednotlivých službách IOMO pripisujeme pandemickej situácii, nakol'ko v roku 2020 vypukla pandémia COVID-19 a pri službe IOMO ide o asistovanú službu na pobočkách poskytovatel'ov. Opatrenia vlády SR ovplyvnili využívanie prezentovaných služieb nakol'ko orgány štátnej správy neposkytovali svoje služby v bežnom režime.

Grafické znázornenie využívania služieb IOMO prostredníctvom ZMOS môžeme vidiet' na obrázku 1.

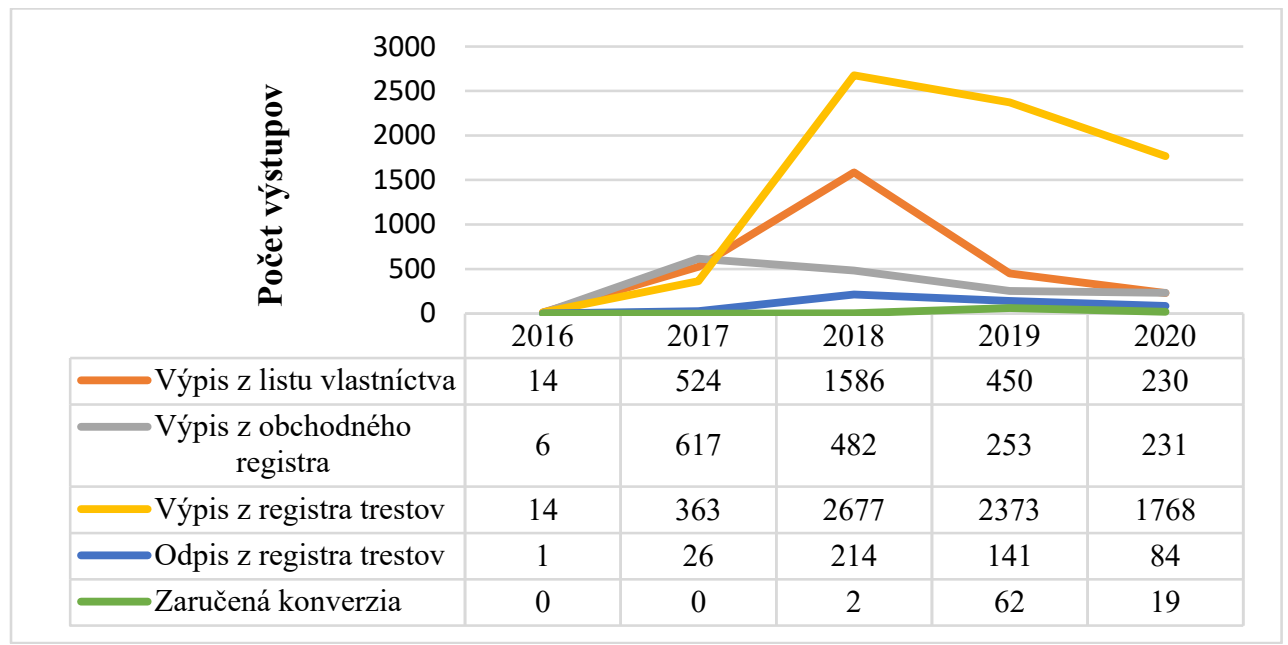

Obrázok 1. Využívanie služieb IOMO u ZMOS (Zdroj: DataLab [online]. [2021-10-10]. Dostupné na internete: $<$ https://datalab.digital/informacny-panel-is-iom/>.)

Ďalším poskytovatel'om služieb IOMO je SP, a. s., ktorá poskytuje elektronické služby už od roku 2011. Analyzované dáta pochádzajú od roku 2016 do roku 2020.

V roku 2016 SP, a. s., poskytla 594412 výstupov služby IOMO. Z toho bolo poskytnutých:

- 307866 výpisov z registra trestov,

- 31547 odpisov $z$ registra trestov,

- 38022 výpisov z listu vlastníctva

- 216977 výpisov $z$ obchodného registra [11]

V roku 2017 bolo prostredníctvom SP, a. s. celkovo poskytnutých viac výstupov, a to 632280 výstupov, čo predstavuje nárast oproti roku 2016 o 37868 výstupov. Z celkového počtu poskytnutých výstupov v roku 2017 bolo uskutočnených:

- 324 641výpisov z registra trestov,

- 32403 odpisov $\mathrm{z}$ registra trestov,

- 41566 výpisov z listu vlastníctva,

- 233327 výpisov $\mathrm{z}$ obchodného registra

- 343 zaručených konverzií. [11]

V roku 2018 bolo celkovo poskytnutých menej výstupov ako predošlé roky, a to 578843 výstupov. Pokles predstavoval 53437 výstupov. Z celkového počtu poskytnutých výstupov bolo realizovaných:

- 292214 výpisov z registra trestov,

- 34 287odpisov z registra trestov,

- 35397 výpisov z listu vlastníctva,

- 214064 výpisov z obchodného registra

- 2881 zaučených konverzií. 
Skokový pokles poskytovaných služieb pripisujeme taktiež spomínanému vládnemu nariadeniu, prostredníctvom ktorého občania a podnikatel'ské subjekty nemajú povinnost' predkladat' výpisy z listu vlastníctva. [11]

Slovenská Pošta poskytla v roku 2019486392 výstupov z informačného systému IOMO. V porovnaní s rokom 2018 ide o viditel'ný pokles poskytovaných služieb o 92451 realizovaných výstupov. Z celkového počtu poskytovaných výstupov za rok 2019 bolo poskytnutých:

- 258725 výpisov z registra trestov,

- 25752 odpisov $\mathrm{z}$ registra trestov,

- 21447 výpisov z listu vlastníctva,

- 174020 výpisov z obchodného registra

- 6448 zaručených konverzií.

Klesajúci dopyt o poskytované služby pripisujeme vládnym nariadeniam z roku 2018.

V roku $2020 \mathrm{SP}$, a. s. poskytla $\mathrm{z}$ informačného systému IOMO celkovo 317400 výstupov. Opät' sa jedná o pokles poskytovaných služieb o 168922 výstupov.

$\mathrm{Z}$ celkového počtu poskytovaných výstupov SP, a. s. realizovala:

- 159193 výpisov $z$ registra trestov,

- 18027 odpisov $\mathrm{z}$ registra trestov,

- 13154 výpisov z listu vlastníctva,

- 116290 výpisov z obchodného registra

- 10736 zaručených konverzií.

Pokles poskytovaných služieb za rok 2020 môžeme pripisujeme nepriaznivej pandemickej situácii spojenej s ochorením COVID-19 Grafické znázornenie jednotlivých výsledkov môžeme vidiet' na obrázku 2.

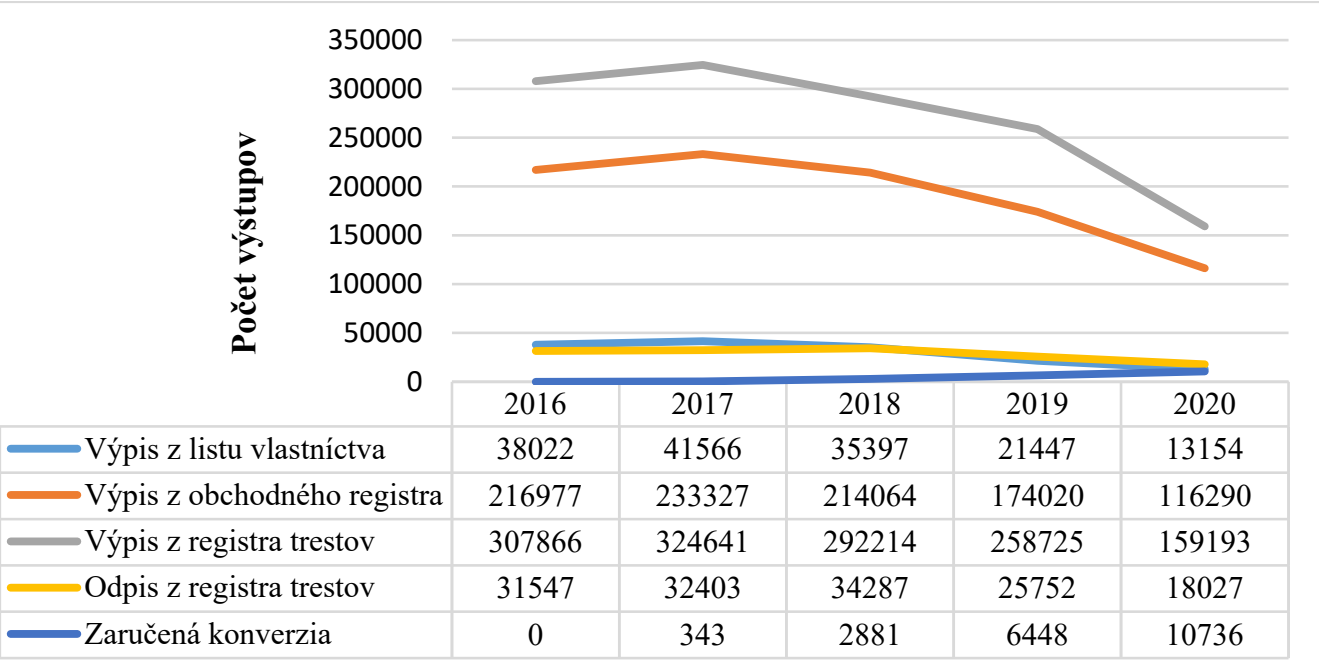

Obrázok 2. Využívanie služieb IOMO na SP, a. s. (Zdroj: DataLab [online]. [2021-10-10]. Dostupné na internete: $<$ https://datalab.digital/informacny-panel-is-iom/>.)

Z analýzy kvantitatívnych dát o skutočnom využívaní služieb IOMO vyplýva, že dopyt po daných službách má klesajúcu tendenciu. Takýto pokles môžeme vidiet' u poskytovatel'ov ZMOS a SP, a. s.

\section{Záver}

$\mathrm{Na}$ základe prezentovaného sekundárneho výskumu sme zistili, že nastal pokles využívania služieb, ktorý je ovplyvnený viacerými faktormi. Práve z tohto dôvodu je potrebné 
sa zamerat' na spôsob, akým by dané pracovisko IOMO mohlo poskytovat' nový spôsob využívania jednotlivých služieb pomocou spolupráce s odborníkmi v oblasti digitalizácie a tým ho zatraktívnit', následkom čoho by prišlo k posilneniu imidžu a reputácie podniku atd'.

Podl'a prierezu využívania služieb IOMO v posledných rokoch je teda možné konštatovat', že využívanie daných služieb má klesajúcu tendenciu. Je potrebné podotknút', že využívanie daných služieb už nie je tak frekventované, čomu pomohol zákon 177/2018 Z. z. Zákon proti byrokracii. Stále ale existuje potreba výstupov pre rôzne neštátne inštitúcie ako banky a preto je táto služba potrebná a nie je možné ju prestat' poskytovat' aj napriek klesajúcej tendencii jej využívania.

V prípade Slovenskej pošty sa jedná o zmluvu na poskytovanie informačného systému IOMO až do 12.9.2023. Z interných informácií SP, a. s. je možné ale konštatovat', že oproti roku 2020 nastal opät' náraz v poskytovaní daných služieb.

\section{Literatúra}

[1] Digitálna ekonomika, čast' prvá: Digitál nie je len IT [online]. [cit. 01. 10. 2021]. Dostupné na internete: $<$ https://dennikn.sk/blog/1349422/digitalna-ekonomika-nie-je-len-it/>.

[2] GEROGIADIS, K. CH., STIAKAKISA, E., RAVIDRANA, A. R. Editorial for the specialissue: Digital Economy and E-commerce Technology.[online]. [cit. 01. 10. 2021]. Dostupné na internete: <https://link.springer.com/article/10.1007/s12 351-011-01226? fbclid=IwAR1MH7cP8 u8vpL_czvk PDiAbG1 RYU_DaU mVp _FyTiYZi3_2DB5nADTfYqs>.

[3] House of Commons. The Digital Economy. [online]. [cit. 04. 10. 2021]. Dostupné na internete: $\quad<\mathrm{https}: / /$ publications.parliament.uk/pa/cm201617/cmselect $/ \mathrm{cmbis} / 87$ 187.pdf?utm_source=87\& utm_medium =Module\&utm_campaign=Modulerepor ts\&fbclid=IwAR3eWHjP12i3VZSc3dAk-gpK-37XE4_AoNU1iiJDeAePgYTrmAjutoBmnU>.

[4] VACULÍK, J., OTTO, I. Analýza mobilných aplikácií vybraných národných poskytovatel'ov poštových služieb. Pošta, telekomunikácie a elektronický obchod.[online]. 2017, vol. 12, no. 1. [cit. 2021. 06. 10]. Dostupné na internete: $<$ https://ks.uniza.sk/casopis/pdf /I2017/I2017.pdf?fbclid=IwAR2Thx3CmIoOXb4WYcyTDWxJiqOEEdClyuOXW5DXZvrwA0_ 9r zR6aWkb0bo>. ISSN1336-8281

[5] ŠTOFKOVÁ, J. a kol. Manažment verejnej správy. Žilinská univerzita v Žiline/EDIS, 2019, 200 s. ISBN 978-80-554-1586-4.

[6] MADLEŇÁKOVÁ, L. Vplyv Industry 4.0. na podmienkach poskytovatel’a univerzálnej poštovej služby. Pošta, telekomunikácie a elektronický obchod.[online]. 2020, vol. 15, no. 2. [cit. 2021 06. 10]. Dostupné na internete: <https://ks.uniza.sk/casopis/pdf/II2020/II2020.pdf?fbclid=IwAR1PU6y2_0F38 eIkNjZqA7_C4WpqgSXh9QmXWtksZTlp-sNJ $\mathrm{x} 3 \mathrm{Ytxy} 8 \mathrm{x} 3 \mathrm{w}>$. ISSN 1336-8281.

[7] ČOREJOVÁ, T. a kol. Ekonomika sieti. Žilinská univerzita v Žiline, EDIS, 2010. 322 s. ISBN 9788055401553.

[8] Elektronické služby e-Governmentu[online]. [cit. 07. 10. 2021]. Dostupné na internete: $<\mathrm{http}: / / \mathrm{www} . \mathrm{mvcr} . c z /$ clanek/elektronicke-sluzbyegovernment.aspx $>$.

[9] Zákon č. 324/2011 Z. z. Zákon o poštových službách a o zmene a doplnení niektorých zákonov. 
[10]MDVRR. Strategické dokumenty. 2019. [cit. 30. 09. 2021]. Dostupné na internete: $<$ https://www.mindop.sk/ministerstvo-1/postove-sluzby-9/strategickedokumenty $>$.

[11] Informačný panel IS IOM. [online]. [cit. 30. 09. 2021]. Dostupné na internete: $<$ https://datalab.digital/informacny-panel-is-iom/>.

[12]Zákon č. 177/2018 z 21. Júna 2018, Zákon o niektorých opatreniach na znižovanie administratívnej zát'aže využívaním informačných systémov verejnej správy a o zmene a doplnení niektorých zákonov (zákon proti byrokracii).

\section{Grantová podpora}

Príspevok bol spracovaný v rámci riešenia projektu VEGA 1/0518/19. 